\title{
sciendo
}

This journal provides immediate open access to its content under the Creative Commons BY 4.0 license. Authors who publish with this journal retain all copyrights and agree to the terms of the above-mentioned CC BY 4.0 license.

\section{DEROGATION OF HUMAN RIGHTS AND FREEDOMS IN RNM DURING THE STATE OF EMERGENCY CAUSED BY COVID-19}

\author{
Prof. Dr. Abdulla Azizi, \\ Faculty of Contemporary Social Sciences, South East European University, \\ Tetovo, North Macedonia \\ a.azizi@seeu.edu.mk
}

\begin{abstract}
Considering that in times of state of emergency or civil emergency (such as the pandemic caused by COVID 19), governments in many countries around the world have restricted human rights and freedoms through legally binding government decrees. These restrictive measures increasingly raise dilemmas about their effect and possible violations by the government of international norms guaranteeing human rights. The paper aims to analyze whether these restrictive measures set out in the decisions of the Government of the Republic of Northern Macedonia (RNM) are in compliance with the derogations allowed under the European Convention on Human Rights and Freedoms (ECHR) and the positive laws in power. In the framework of this paper is analyzed whether these measures have the sole purpose of protecting the health of citizens or not.
\end{abstract}

The work is limited in terms of time (as long as the state of emergency lasted three months) and territory (government decrees with the force of law).

Descriptive, historical, analytical, comparative and citizen survey methods are used in this paper.

Government decrees have been analyzed in order to assess whether they were prudent, in accordance with international standards and consequences that they have caused to citizens. 
The conclusions provide data on whether the management of the situation has been appropriate or not and to what extent it has been effective, as well as how much it has been within the international framework and how they have affected the quality of life of citizens.

Key words: human rights, government decisions, ECHR derogations.

\section{INTRODUCTION}

After the World Health Organization (WHO) on March 11, 2020 had confirmed the coronavirus pandemic COVID-19, the President of the RNM had declared the Decree on State of Emergency lasting one month (Decision, 2020). However, the state of emergency was extended 5 times in a row (the first and second time with a duration of 1 month, the third and fourth time with a duration of 15 days, and the fifth time with a duration of 8 days) until June 22. Two days after the end of the state of emergency, the election campaign for the parliamentary elections (which were held on July 15) had begun.

As a result, the Permanent Representation of the RNM to the Council of Europe had notified the Secretary General of the Council of Europe on 2 April 2020 that the RNM would be temporarily withdrawn from its ECHR implementation obligations throughout the country (Note Verbale, 2020).

Thus, the Government of the RNM was given the opportunity to adopt decisions with legal force, with the aim of temporarily suspending or restricting certain fundamental human rights and freedoms as long as the state of emergency lasts, but with a focus on protecting the public health of the population.

The measures adopted by the Government of RNM were related to: the suspension of the regular teaching process in the classrooms at all levels of education (replacing it with distance learning from home); restricting public gatherings, public events, meetings; closing museums, theaters and cinemas for visitors; cancellation of performances and conferences, suspension of international passenger flights; establishing special rules of isolation and quarantine organized by the state for citizens entering the territory of the RNM; prohibition and special regime of movement of citizens; quarantine of some settlements, curfew throughout the territory and in some settlements, etc. (Government Decrees, 2020).

The implementation of these government measures significantly affected the suspension of the rights and freedoms established by the ECHR. Their suspension had to be proportionate and 
deliberate, imposed by the state of emergency and not contrary to international law. It is important to note that the Strasbourg Court of Human Rights and Freedoms (hereinafter the Strasbourg Court) when considering cases related to (un)taken measures by states during the COVID-19 crisis, will address the possible consequences from the derogation, from the moment of the above notice including all further steps that the RNM will take until the date when the derogation will cease (CoE Note Verbale, 2020). The EU Agency for Fundamental Rights (FRA) also claims that this crisis will present a new challenge for domestic courts, which will have to assess the necessity and proportionality of the measures (Coronavirus Pandemic, FRA 2020).

The measures implemented to stop the spread of COVID-19 significantly affected the quality of life and affected basic human rights, in particular: the right to inclusive education (not all children had access to the Internet and owned electronic devices such as smartphones, tablets or laptops); reduction of workers' salaries or their dismissal from work; lack of access to social rights, services and goods; increasing domestic violence; protection of privacy and personal data; affect specific groups (children, people living in poverty, the homeless, people with disabilities, the elderly, people living in nursing homes, prisoners, Roma, women at risk of domestic violence, etc.), and raised the issue of equal treatment.

The situation turned out to be difficult, as the courts weren't fully operational, when the work was done remotely by conducting proceedings through video conferencing, especially when the judicial system wasn't adapted to the use of such technology. As the courts either stopped working altogether or decided on cases behind closed doors, this led to numerous violations of court proceedings, which at the same time constitutes a violation of Article 6 of the ECHR for a fair trial.

Although at the beginning of the state of emergency there was strong support for measures adopted by the government regarding the restriction of freedom of movement due to the danger posed by Covid-19, this support over time began to fade as a result of the consequences that were presented by the implementation of preventive measures and failure to achieve the expected results.

What the citizens didn't seem to agree with was the avoidance of state obligations to citizens, especially when government measures weren't proportionate and necessary. 
What emerged as a real problem was the need for detailed monitoring and transparency regarding ECHR derogations. Moreover, there is a lack of a mechanism to monitor the ongoing derogation and the Council of Europe's limited institutional capacity to monitor derogations from all its member states. The call for transparency was probably the most important instrument available to citizens to protect human rights.

Any restriction or deprivation of the right to protection under the ECHR had to be clearly stated and explained. Reporting of evasions didn't occur, although the information was discussed at government hearings, but no further action was taken to inform the public that the state was reporting to the Strasbourg Court that during this period it couldn't guarantee private and family life, the right to education, freedom of assembly and association and freedom of movement (Kotevska, 2020: 13).

\section{LEGAL BASIS FOR DECLARING "A STATE OF EMERGENCY"}

The initial question that arose at the beginning of Covid19 was whether a state of emergency or a state of crisis should be declared? Article 125 of the Constitution of the Republic of Macedonia states that "A state of emergency may be declared when major natural disasters or epidemics occur. The decision must be approved by a majority of $2 / 3$ of the total number of deputies and is valid for 30 days. If the Assembly cannot convene, such a decision shall be taken by the President of the State and submitted to the Assembly for approval as soon as possible."

Article 126 of the Constitution states "In case of a state of emergency, the Government based on the Constitution and laws, adopts Decrees with legal force". This authorization lasts until the end of the state of emergency, which is decided by the Assembly.

Thus, Government decisions during the state of emergency are immediately effective for an urgent and more efficient treatment of the pandemic.

The opposition political party VMRO-DPMNE, through its leader Mickoski, said that "a state of crisis should be declared". However, this term is not found in the Constitution, but in the Law on Crisis Management, Article 30 of which stipulates that "A state of crisis is a situation that poses a threat to the well-being, health and life of people, animals or a threat to the safety of the state or a part of its territory, for which there are no conditions for declaring a state of emergency. "So, despite the state of emergency, "the crisis situation" is a kind of limitation, 
which can affect the effectiveness of government measures in dealing with the pandemic. The Crisis Management Act states that the crisis cannot last more than 30 days. If there is a need for a longer period, then the Assembly must approve it, which was impossible because the Parliament was out of order; or as a second option, if the crisis situation persists, then a state of emergency is declared. So again the continuation of the crisis implies a state of emergency, but that will be delayed for 30 days, instead of being declared immediately. Unlike the emergency situation in which the Government has the main say, in a crisis situation the main body would be the Crisis Management Center (CMC) which would have to act in accordance with the law, which means that the headquarters of crises would have to arise throughout the country, which would mean the involvement of a much larger number of people, which is not recommended in a pandemic situation.

The difference also lies in the effectiveness of measures that the government can take to prevent and correct the economic consequences. Moreover, a state of emergency was declared in most countries in the region and in EU member states. Of course, the state of emergency is the first experience for the RNM and the government in such a situation is already gaining additional power, but it should not be understood that it is becoming a center of power that will jeopardize the position of other institutions. In another situation, if a state of emergency had not been declared, the Government would have to follow the narrow legal frameworks which regulate the functioning of numerous institutions and bodies, while any circumvention of them would mean a deliberate violation of the rules. However, the situation requires that due to unpredictability, the legal framework be exceeded because it may be insufficient in a situation where things change from hour to hour, and the deterioration of the situation automatically means greater mobilization, human, material and financial resources etc., which means management beyond established legal norms (Bakreski, 2020).

\section{LIMITS ON ECHR RESTRICTIONS THROUGH GOVERNMENT MEASURES}

Although the ECHR allows derogation from the obligations of the member states of the Council of Europe, in a state of emergency in relation to the protection of health (Article 5, paragraph 1, Articles 8-11, Article 2, point 3 of Protocol No. 4), the states themselves assess the nature and extent of the derogations. The Secretary General of the Council of Europe (as the guarantor 
of the implementation of the Convention) must be informed of this, of the measures taken, the reasons and the moment of termination of these measures.

Under the above provisions, all member states of the Council of Europe may waive certain obligations under the ECHR for a certain period of time and under certain conditions. Under Article 15 "Derogation in a state of emergency" is allowed in the event of "war or any other general danger endangering the life of the nation", but only in a "limited and supervised manner" without affecting the articles of the ECHR as follows: 2 (right to life), 3 (prohibition of torture), 4 (prohibition of slavery and forced labor), 7 (no unlawful punishment), 4 of Protocol No. 7 (double trial and punishment for the same offense), as well as Article 2 of Protocol No. 13 and Article 3 of Protocol No. 6.

Article 15 of the ECHR provides for the fulfillment of certain material and procedural conditions that the deviation from the application of the ECHR be considered permissible.

Material conditions are related to:

- Confirmation of the true existence of an emergency, which threatens the life of the nation and has no malicious intent by the government;

- It is necessary that the measures present a response to the emergency situation and they are justified, but should not be abused;

- The measures must be in accordance with the international obligations of the state.

The procedural conditions imply the existence of a legal act derogating from the implementation of the ECHR, the notification to the Secretary General of the Council of Europe that the State concerned will waive Article 15 of the Convention, the reasons, taken measures and the notification that the derogation will end.

However, the state of emergency also bears responsibility for possible human rights violations by the government, which will be the subject of treatment by the Strasbourg Court immediately after the end of the state of emergency, when cases of possible violations will be presented to it.

Therefore, it is important to demand accountability from the authorities and a limit should be set on giving new broad powers to the executive (Dzehtsiarou, 2020).

Even in emergency situations, the rule of law must prevail and government actions must be in accordance with the law (Venice Commission, 2006), while decrees with legal force must be based on the Constitution and international standards. However, the Assembly must continue 
to retain the power to control the actions of the executive (PACE recommendation, 2005: 38), with the possibility of modifying or annulling unjustifiable decisions (Venice Commission, 2016). The dissolution of the Assembly during the state of emergency should not be allowed and its mandate should be extended until the end of the state of emergency. The basic function of the judiciary, especially the Constitutional Court, must continue to be maintained, and it is important that judges be able to review the most severe human rights restrictions imposed by legally binding emergency decrees (CoE Informative document, 2020: 5).

The main social, political and legal challenge that the state is facing will be the ability to respond effectively to this crisis, while guaranteeing that the measures taken will not violate the values of democracy, the rule of law and the human rights. It is here that the Council of Europe must implement its core mandate by providing all relevant mechanisms $(\mathrm{CoE}$ Information document, 2020: 2).

The European Network of National Human Rights Institutions (ENNHRI) had brought together over 40 National Human Rights Institutions (NHRIs) across Europe in order to increase the protection of human rights in the region. NHRI in Europe has been monitoring the reactions of states since the beginning of the pandemic and has advised governments and national parliaments on human rights standards as well as informing the public about their rights during this crisis. All countries in Europe are committed to upholding human rights, democracy and the rule of law, including the ECHR, the EU Charter of Fundamental Rights and the UN Charter (ENNHRI, 2020).

\section{CONCERNS ABOUT DISCRIMINATION AGAINST PERSONS WITH DISABILITIES, VICTIMS OF DOMESTIC VIOLENCE AND PERSONS WITH COVID-19}

The question is how much the government managed to protect the health of citizens through its protection measures? According to an analysis of the TV show "KOD" at the national television Telma, 9 patients with COVID19 died at home (instead of being hospitalized) after failing to be tested, while 7 other people died without receiving the results from testing. A person with a disability, Robert Jankovski from the Radisan neighborhood (Skopje district), was one of the victims of the coronavirus, whose relatives claim that "He died after the algorithm rejected him for testing and due to that he was not hospitalized." After he died, the result from the post-mortem testing was positive. This raised suspicions when his family 
members stated that "people with disabilities also have the right to life" (TELMA KOD, 2020). So $20 \%$ of those infected were not treated in hospital even though they were infected with coronavirus, but haven't been detected timely through testing (TELMA KOD, 2020) which raises the dilemma for the quality of testing by health institutions as a result of which people lose their lives.

Given that restrictive measures to protect against COVID-19 increase the risk of domestic violence, the Office of the UN High Commissioner for Human Rights (OHCHR, 2020) called on governments to respect women's rights and children and find urgent measures for victims of violence. The UN Special Rapporteur on violence against women, Dubravka Simonovic, recalls the possibility of an increase in domestic violence based on initial police reports and SOS phone calls. Measures to protect victims should remain available even in times of crisis, e.g. rapid police response, activation of SOS lines and provision of telephone and online messaging services, taking into account the risks of home calls. The risk of violence increases when there are insufficient services, such as assistance and care in Shelter Centers also when access to services is difficult and community support is low and in a period when many institutions are closed.

The Anti-Discrimination Network had issued a statement urging the government and relevant institutions to take measures to prevent harassment and violation of the rights of people positive with Covid-19 and people suspected of being infected (Coalition, 2020). A number of articles appeared in the media, mainly on Internet portals, where photos, names and lists of citizens who are positive with Covid-19 or who are suspected to be positive were published. This is seen as problematic and harmful in many respects. First, in addition to the health and economic crisis, the Law on the Protection of Patients' Rights guarantees the right to confidentiality of patients (Article 59, paragraph 19), which means that health personnel should not publish any data related to the situation patient health (including Covid-19 status). Thus, the Personal Data Protection Agency should act and sanction those cases as the publication of personal data of persons infected with Covid-19 is endangering the safety and well-being of patients, exposing them to public lynching, are declared dangerous for public health, are blamed for the spread of the pandemic, are seen as irresponsible, unscrupulous and dangerous citizens. Thus, patients themselves are exposed to discrimination, precisely because of their health status. This also violates the Law on Prevention and Protection against Discrimination, which prohibits discrimination on the grounds of health status (Article 5). If all citizens continue to adhere to 
measures for physical distancing and hygiene, regardless of whether we have a positive, negative status or have not taken a test for Covid-19, the chance of infection regardless of whether we were close to a sick person is reduced. Therefore, the attention of the media and the public should be focused on the implementation and observance of the measures, and not on the individuals who are infected.

\section{ANALYSIS OF THE ADEQUACY OF GOVERNMENT MEASURES WITH ECHR}

In a notification to the Secretary General of the Council of Europe, the Government of RNM had expressed the need to relinquish its obligations under Article 8 (right to respect for private and family life), Article 11 (freedom of assembly and association), Article 2 of Protocol No. 1 (right to education) and Article 2 of Protocol No. 4-freedom of movement (Verbal Note, 2020).

Since as a result of the Covod-19 pandemic people are dying in significant numbers, then Article 2 of the ECHR can be activated, which requires states not only to refrain from arbitrary actions, but also to protect the lives of those who are in their jurisdiction. Similarly, Article 3 requires states to refrain from ill-treatment, but also to take certain steps to protect their citizens from grievous bodily harm or suffering. Unfortunately, some state governments have spoken out for collective immunity (the case of the United Kingdom), which meant that a significant number of the population would have to become ill to develop immunity to the virus. As a side effect, some elderly people with other diseases had died. Thus, the case can be brought before the Strasbourg Court to determine whether the victims had died as a direct result of the (non)actions of the state, otherwise states will have to prove why they have failed to protect people's lives. Such a causal link would have to be proven for the Strasbourg Court to find a violation of Article 2 of the ECHR.

Lack of medical treatment can be seen under the definition of Article 3 of the ECHR (prohibition of torture). Although many diseases lead to considerable suffering and some may even be fatal, the Strasbourg Court cannot blame the state for this; but the state is nevertheless obliged to provide proper care. If the state fails to provide proper medical assistance, then such a violation is possible. However, in the circumstances of Covid19 and the large number of potential victims, the meaning of the phrase "adequate care" changes. If it happens that there are not enough beds available in hospitals, then the Strasbourg Court is unlikely to find a 
violation of the ECHR and it is difficult to prove whether government policies were a reason for overcrowded hospitals during the pandemic.

Derogations related to Article 5 (Rights to Freedom and Security) entitle the government to intervene with measures to prevent the spread of the pandemic. Arrests and "deprivation of liberty" should be linked to violations of clearly defined norms and should be significant. In the case of restriction of freedom of movement, it remains unclear whether, for example, a person has violated freedom of movement, if he belongs to a group of citizens who are not obliged by restrictive measures (farmers, doctors, food carriers, senior state officials), or in the term of movement restriction, persons who have problems with domestic violence or for any need have gone to the competent institutions, in emergency cases to the pharmacy or family doctor. In all cases, it depends on the discretionary assessment of law enforcement officers whether the person in question will be deprived of his liberty or not and whether he will be fined. The arbitrary decision may be contrary to the ECHR.

Temperature measurement and reporting on an individual's international travel is also a human rights violation under Article 8 (Right to privacy). Any legal intervention in this regard should be related to the proportionality of the measures related only to the protection of public health and not more, because this may lead to different interpretations of the ECHR for which liability may be sought for violations by state.

Articles 9 (Freedom of religion) and 11 (freedom of association) may be restricted and justified if they are used to prevent the spread of the pandemic. If these measures are not necessary and the pandemic is used as a pretext to silence any religious group, then the Strasbourg Court may find a violation of the Convention. Prohibition of gatherings in places of worship (mosques, churches, etc.), sports halls, scientific events, etc. must be justified by a significant threat from the pandemic. In the case of the RNM, the violations were tolerated by the police during the opening of the Orthodox Church in Skopje in celebration of the Easter holiday in circumstances when, according to government norms, the gathering of more than 2 people was prohibited. The move, which came just days after the government banned rallies and prayers in mosques, was seen as a discriminatory approach by the government to the Muslim community. "The Macedonian Autocephalous Church did not close the churches for the religious holiday" Easter "on the night between 19 and 20 April 2020 and had invited the faithful, while the Government did not intervene to stop the commotion." This happened in circumstances when the freedom of movement of every citizen a month earlier was restricted by Government Decision due to 
the corona virus pandemic in the country and curfew was imposed. Measures to prevent the spread of corona virus, stopped the grouping of more than two people in the same place, and recommended a social distance of 2 meters even in cases where citizens can move to perform their daily duties (from 16:00 to at 05 hours on weekdays). Earlier, the Macedonian Orthodox Church announced that the churches would be open for liturgy for the upcoming holidays, but only 5 believers would be admitted at the same time, wearing masks or scarves. In this case, not only were the rules violated, but a good international example was not followed on the occasion of a similar ceremony celebrated by Catholic believers, when the Pope at the Vatican was serving alone an Easter liturgy a week earlier, when all churches were closed (SDK, 2020). For the second time there was a violation, when the Macedonian Orthodox Church held a solemnity for the Orthodox spring religious holiday "Gjurgjovden". Several thousand Orthodox believers did not respect the distance of 2 meters nor did they wear protective masks in the liturgy of May 7, 2020, which was held at the "Bigorski" Monastery in Struga. From the recorded images, citizens who had come for the liturgy were noticed, while recordings and photos from the event were published on several web portals (SHENJA \& ALSAT, 2020). After this event, the Albanian political opposition reacted, namely the Alliance for Albanians had accused the government of double standards for the second time in a row against citizens and religious communities (ALLIANCE, 2020), while Arben Taravari had stated that "If it is true, it is scandalous" (TV21, 2020). Then the Minister of Health-Venko Filipce reacted and emphasized that he will seek responsibility and stated that the case should be investigated. However, this remained only as communication through Facebook to animate the public, and in fact there was neither procedure for breaking the rules nor responsibility for organized breaking the rules regarding restricting movement during the pandemic. The Alliance for Albanians alluded to the case of 13.04.2020 when in the Hasanbeg neighborhood (otherwise called Singiliq) of Skopje were arrested 3 Albanian citizens for violating the curfew in front of their homes in the alley of the street where they live. This was followed by a protest by the residents of the neighborhood to release the persons detained by the police. In further proceedings, after two days, the Prosecution requested a fine for each person with a fine of 5 thousand euros for non-compliance with health recommendations during the pandemic (ALSAT, 2020).

From the above cases we can conclude that violations of ECHR provisions during the COVID19 pandemic are obvious and premeditated. It is important to note that the government has not 
been careful to avoid discrimination in the implementation of protection measures for public health through the actions of institutions.

\section{POSITIVE OBLIGATIONS OF THE STATE FROM THE EXPERIENCE OF THE STRASBOURG COURT}

It is clear that the state can violate human rights not only by actively acting, but also by not acting to protect citizens. The Strasbourg court usually reminds states that they must justify the austerity measures they have taken in relation to the serious threats to the health of citizens and through which they have created obligations for persons under their jurisdiction. State obligations under the ECHR are considered as positive obligations to protect citizens and they should be related to the respective context and risk (Mavronicola, 2020). Positive obligations under Article 3 of the ECHR must be oriented towards ensuring "practical and effective protection" of rights (Case Valiulienè v Lithuania, 2013), which means:

- the duty of the state to establish appropriate legal provisions and enforcement mechanisms for the protection of life, bodily or mental integrity;

- operational measures to protect persons at real risk, when the authorities know or should know about the risk;

- the investigation of cases of torture, inhuman or degrading treatment or punishment.

General measures mean the creation of a legal framework and mechanisms to protect the life, physical and mental integrity of citizens, but also operational measures to address real and immediate risks to life, which come from violent and illegal actions by others or from natural hazards (Stoyanovi v Bulgaria, para 61).

Measures taken should include adequate protection through protective equipment; effective management planning and provision of emergency health care and effective nondiscriminatory access to essential goods and services. This further means that states must take reasonable steps to ensure the livelihood and well-being of the people, as well as to alleviate other risks that may arise from austerity measures. The group of responsibilities also includes initiatives to provide financial support to people who have lost their source of income. With regard to persons with special needs and persons deprived of their liberty, positive obligations are added to protect their physical and mental life and integrity. The defined measures related to the positive obligations of the state, should not only be oriented towards a certain protection, but should definitely realize the real protection within the framework of the ECHR (Opuz v 
Turkey, para 129). In order for the positive measures taken to ensure effective protection to be reasonable and appropriate, they must be adapted to the relevant circumstances which change day by day. Thus, measures taken in response to the COVID19 pandemic need to be constantly monitored and reviewed depending on changes in the situation. Therefore, the state should take all reasonable steps to decide and respond to changes during the pandemic, as well as the risks associated with it, including the risks arising from the measures taken to deal with this pandemic, such as if as a result of the measures the risk of domestic violence has increased.

\section{SURVEY}

For the purposes of this paper, a survey of citizens was conducted in the RNM. The questionnaire used in this research is composed of 17 questions. It is designed to include data on the demographic and socio-economic status of respondents, as well as responses to their perceptions. Field research was conducted on the basis of a questionnaire consisting of general questions about the situation regarding citizens' attitudes. In this survey, 1113 citizens over the age of 18 were included. Within the Questionnaire there are seven questions related to the following variables:

1. Residence - Village (52\%), City (48\%);

2. Age - 18-30 (5\%), 31-40 (32\%), 41-50 (35\%), over $51(30 \%)$;

3. Marital status - Married (59\%), Unmarried (17\%), Divorced (5\%), Widower (9\%);

4. Education - Uneducated (5\%), with elementary school (30\%), High school (41\%), with faculty and more (24\%);

5. Employment status - Unemployed (70\%), Employed (30\%);

6. Net monthly household income in $€$ - Up to 150 (17\%), 150-250 (22\%), 250-350 (23\%), $350-450$ (23\%), 450-550(13\%), over $550(2 \%)$;

7. Number of members in the family - One (3\%), Two (8\%), Three (30\%), Four (40\%), Five (19\%), Six and more (2\%).

While questions have to do with respondents' perceptions of the issues that are a matter of research. 
The details are in the following table:

\begin{tabular}{|c|c|c|c|}
\hline Question & Yes & No & I don't know \\
\hline $\begin{array}{l}\text { Are government measures justifiable for the continued restriction of } \\
\text { the movement of citizens? }\end{array}$ & $43 \%$ & $39 \%$ & $18 \%$ \\
\hline $\begin{array}{l}\text { Do you think that the government, with the measures taken to restrict } \\
\text { the freedom of citizens, exceeds its constitutional competencies and } \\
\text { international obligations? }\end{array}$ & $23 \%$ & $61 \%$ & $16 \%$ \\
\hline $\begin{array}{l}\text { After the situation normalizes, will you complain to the judicial } \\
\text { authorities about the violation of your fundamental rights? }\end{array}$ & $9 \%$ & $59 \%$ & $32 \%$ \\
\hline $\begin{array}{l}\text { Have you encountered obstacles during the realization of your basic } \\
\text { family needs as a result of limitations? } \\
\text { Reasoning: Measures to restrict the freedom of citizens have caused } \\
\text { obstacles to the citizens to fulfill their daily obligations. In particular, } \\
\text { there have been riots in supermarkets for the supply of food products, } \\
\text { especially during the holidays, riots in front of banks by elderly } \\
\text { people to receive pensions, etc.) }\end{array}$ & $48 \%$ & $23 \%$ & $29 \%$ \\
\hline $\begin{array}{l}\text { Have restrictive measures affected your family life? } \\
\text { Reasoning: The negative effect that restrictive measures have had on } \\
\text { the lives of citizens are multiple, as in social, emotional, economic, } \\
\text { sports, professional, tourism, health life }\end{array}$ & $85 \%$ & $8 \%$ & $7 \%$ \\
\hline $\begin{array}{l}\text { Do you think that the situation created by COVID-19 will affect the } \\
\text { reconceptualization of your social life in the future? }\end{array}$ & $55 \%$ & $24 \%$ & $21 \%$ \\
\hline $\begin{array}{l}\text { Have the measures to restrict the freedom of citizens been } \\
\text { unjustifiable given the result achieved? }\end{array}$ & $40 \%$ & $37 \%$ & $23 \%$ \\
\hline $\begin{array}{l}\text { Do you think that the competent institutions (police, labor } \\
\text { inspectorate, etc.) have been able to follow accurately the } \\
\text { implementation of restrictions in practice? }\end{array}$ & $45 \%$ & $41 \%$ & $14 \%$ \\
\hline $\begin{array}{l}\text { Do you think the government should have organized the restrictions } \\
\text { otherwise, providing for a different schedule of restrictions and } \\
\text { stricter control over them? }\end{array}$ & $39 \%$ & $30 \%$ & $31 \%$ \\
\hline $\begin{array}{l}\text { Do you think that the government with the extension of the restrictive } \\
\text { measures, in addition to "protecting the public interest", also has some } \\
\text { hidden and unknown purpose for the public? }\end{array}$ & $26 \%$ & $44 \%$ & $30 \%$ \\
\hline $\begin{array}{l}\text { Do you justify holding parliamentary elections in a time of pandemic? } \\
\text { Reasoning: As the largest party in power emphasizes that the } \\
\text { elections will take place } 20 \text { days after the end of the state of } \\
\text { emergency? For this dilemma, meetings of political party leaders } \\
\text { with the president of the state were held several times to find a } \\
\text { common language for the date of the parliamentary elections. Most } \\
\text { other political parties have stated that they prefer to go to the polls } \\
\text { when there is better control over pandemics, sometime in July or } \\
\text { later. }\end{array}$ & $32 \%$ & $58 \%$ & $10 \%$ \\
\hline $\begin{array}{l}\text { Does the political interest prevail over the health interest of the } \\
\text { citizens, when it comes to holding parliamentary elections? }\end{array}$ & $71 \%$ & $21 \%$ & $8 \%$ \\
\hline $\begin{array}{l}\text { Do you think that government measures regarding tolerance towards } \\
\text { religious subjects for religious prayers in churches and mosques are } \\
\text { right and in the spirit of protecting public health? }\end{array}$ & $70 \%$ & $29 \%$ & $1 \%$ \\
\hline \multirow{2}{*}{$\begin{array}{l}\text { After } 3 \text { months of restrictions, do you think the state of emergency in } \\
\text { the country should end? }\end{array}$} & slightly & on the average & fully \\
\hline & $52 \%$ & $39 \%$ & $9 \%$ \\
\hline $\begin{array}{l}\text { To what extent have you respected the government's measures to } \\
\text { restrict freedom of movement? }\end{array}$ & $2 \%$ & $13 \%$ & $85 \%$ \\
\hline
\end{tabular}




\begin{tabular}{|l|l|l|l|}
\hline Are your fundamental rights violated during the state of emergency? & $58 \%$ & $29 \%$ & $13 \%$ \\
\hline & $\begin{array}{l}\text { low awareness tolerance of law } \\
\text { of citizens } \\
\text { enforcement } \\
\text { institutions against } \\
\text { violations of citizens } \\
\text { government } \\
\text { measures }\end{array}$ \\
$\begin{array}{l}\text { Do you think that the lack of results (real decrease in the number of } \\
\text { infected people with Covid-19) is due to: }\end{array}$ & $59 \%$ & $26 \%$ & $15 \%$ \\
\cline { 2 - 4 }
\end{tabular}

Based on the report of the Deep Knowledge Group (DKG, 2020), Switzerland is considered to be the safest country in the world in terms of dealing with COVID-19, followed by Germany, Israel, Singapore, Japan, Austria, etc. This report was based on 130 quantitative and qualitative data parameters in categories such as quarantine efficiency, monitoring and detection, health preparation and government efficiency. The most dangerous countries were South Sudan, Rwanda, Mali, Chad, Afghanistan, etc. The USA ranked 58th, just behind Romania and two places ahead of Russia. What is worrying is that the RNM ranks 103rd, while Slovenia is far behind the RNM, in 32nd place, Greece in 34th, Croatia in 36th place and Turkey in 37th place. Of the countries in the region, Montenegro is ranked 42nd, Bulgaria is ranked 48th, while Serbia is ranked 54th. Before the RNM is Bosnia and Herzegovina, which is ranked 72nd, as well as Albania, which is in 88th place (Analytics, 2020).

President Stevo Pendarovski in the weekly interview for "Radio Free Europe" had stated that a part of the society failed to implement preventive measures against the virus. According to him, the responsibility falls partly on the Government, on the religious communities and on those citizens who refused to implement the measures (Slobodna Evropa, 2020). At the level of systematic solution against the pandemic, Pendarovski said that "our country was not at all different from neighboring countries or other countries in the world, and has respected the recommendations of the WHO" (Alsat, 2020). 


\section{CONCLUSION}

During the pandemic situation, citizens were unjustified by state authorities in various ways. State bodies have repeatedly appealed to citizens that only behavior imposed by the government through coercive measures can save their lives. However, this doesn't mean that the state had to give up its positive obligations and accountability for the reasonableness and appropriateness of the measures it has adopted towards ensuring the protection of public health. Government protection measures had to respond to general threats, as well as real and immediate risks to the life, integrity and socio-economic situation of citizens.

To minimize the possibility of a negative effect on marginalized groups in society, a comprehensive approach was required, which would include planning, implementing, monitoring, evaluating and concluding measures related to the restriction of free movement and human rights. Continuous monitoring of the measures was necessary to draw conclusions as to whether the measures taken by the government had resulted in expectations, or should have been changed, as the maintenance of measures that were not needed couldn't be considered a justification under the ECHR.

What had sparked public debate were the delayed (not timely) measures to financially support businesses and affected citizens, when the state of emergency was already coming to an end and the country was on the verge of parliamentary elections. The continuation of the state of emergency by the President of the state in certain cases was assessed as a political game of the executive power and that his decisions were not within the framework of public health protection. This was evident in the last declaration of the state of emergency, when the President declared in front of the media that the need for a state of emergency had ended, although the number of people infected with Covid19 on a daily basis was much higher compared to previous periods when he had declared other emergencies. This had sparked criticism from opposition parties against him and he was seen as a tool in the hands of the government used to lead the country to early parliamentary elections at the request of the government, forgetting to safeguard the public health of citizens. One day after this statement, the President changed his mind and said that the state of emergency should continue for another 8 days, a decision influenced by the Political Agreement between the leaders of the major political parties (Zaev-LSMD and Mickovski-VMRO-DPMNE) for setting the date of the elections on July 15, 2020, elections which should have been held 10 days earlier. 
However, the elections were held, and now the number of infected people continued to increase every day (reaches the daily figure of about 200 infected), so the RNM is estimated to be high in the top list of mortality per capita from COVID19 at European level, in situations when the state of emergency has already legally ended. Thus, now public health care is limited to the instructions of the Ministry of Health to maintain physical distance and use masks in public places. This raises dilemmas in the sincerity of the government for the protection of the public health of citizens, as well as raises doubts in the management of antiCOVID19 measures, in situations where citizens had stayed for 3 months under strict measures of restriction of their freedom and rights, but unfortunately without any result in protecting their health. Therefore, it will not be a surprise if in the near future, there will be cases when the citizens of the RNM will initiate lawsuits against their state before the Court in Strasbourg. 


\section{REFERENCES}

- Bakreski O. (2020), Institute for Security, Defense and Peace at the Faculty of Philosophy, 20.03.2020

- Coronavirus Pandemic in the EU: Fundamental Rights Implications from 01 February to 20 March, FRA, Publications Office of the EU, Bulletin No1, April 2020, Luxembourg

- Directorate of Legal Advice and Public International Law, Note Verbale JJ9021C Tr./005232, Council of Europe, 02.04.2020

- Dzehtsiarou K. (2020), COVID-19 and the ECHR, Strasbourg Observers, 27 March 2020

- ECHR, Case of Stoyanovi v Bulgaria, para 61, 9 November 2010, Strasbourg

- ECHR, Case Opuz v Turkey, para 129, Judgment Strasbourg, 9 June 2009

- ECHR, Case Valiulienè v Lithuania, para 75, Judgment Strasbourg 26 March 2013

- Human Rights Committee, General comment No.36 (2018) para 26, on article 6 of the International Covenant on Civil and Political Rights, on the right to life, 30 October 2018

- Informative Document SG / Inf.2020 / 11. Respect for democracy, the rule of law and human rights in the context of the COVID-19 sanitary crisis. Package for member states, Council of Europe, 7 April 2020

- Kotevska B. (2020, After the shaky steps: On human rights and COVID-19 in RNM after the derogation of the ECHR, April 2020, EPI-Skopje

- Law on prevention and protection against discrimination, Official Gazette of RNM, No.101 from 22.5.2019

- Law on Protection of Patients' Rights "Official Gazette of RNM", No.82/2008, 12/2009, $53 / 2011$.

- Mavronicola N. (2020), "Positive Obligations in Crisis", Strasbourg Observers, 7 April 2020

- Note Verbale of the Permanent Representation of the RNM to the Council of Europe, No. 35 01-155/2, 2 April 2020, Strasbourg

- Now is the time for solidarity on human rights: The need for human rights in COVID-19 responses in Europe, ENNHRI, 23 April 2020

- Opinion of the Venice Commission for the Protection of Human Rights in Emergency Situations, CDL-AD 2006/015, item 13. Adopted by the Venice Commission at its 66th Plenary Session Venice 17-18 March 2006.

- PACE Recommendation of 1713 (2005), Democratic oversight of the security sector in the Member States

- Rule of Law Checklist, adopted by the Venice Commission at its 106th Plenary Session (Venice, 11-12 March 2016), CDL-AD 2016/007-e, item 51

- States at Risk: Big Data Analysis of 100 Countries and Regions Safety Ranking and Risk Assessment. Deep Knowledge, Hong Kong, 2020

- The Decision No. 08-526/2 of 18 March 2020, signed by the President of the RNM, Official Gazette of the RNM No.68, 18 March 2020 


\section{Electronic resources}

- http://analytics.dkv.global/covid-regional-assessment-200-regions/full-report.pdf

- http://coalition.org.mk/дискриминацијата-и-вознемирувањето

- http://ennhri.org/statement-on-covid-19

- http://shenja.tv/filipce-kerkon-hetim-te-shkeljeve-qe-u-bene-ne-manastirin-bigorskine-struge

- http://shenja.tv/kisha-ortodokse-maqedonase-vazhdon-me-mosrespektimin-e-masave-kunderkoronavirusit;https://alsat-m.tv/liturgjia-fetare-ne-struge-shkelen-te-gjitha-masat-kunderperhapjes-se-koronavirusit.

- https://alsat-m.tv/ggjoba-prej-5000-eurosh-per-te-arrestuarit-ne-hasanbeg

- https://alsat-m.tv/pendarovski-deshtuam-ne-zbatimin-e-masave-per-virusin

- https://religija.mk/struga-se-podgotvuva-za-najmasovnata-litija-za-gjurgjovden

- https://sdk.mk/index.php/mk

- https://telma.com.mk/kod-pochina-pred-bolnitsa-pa-dobi-rezultati-od-test-9-patsienti-odkovid-19-pochinale-doma-bez-rezultati-algoritmot-gi-otfrlal-zhrtvite-za-testirane

- https://tv21.tv/liturgjia-ne-struge-taravari-kjo-eshte-skandaloze-ash-kerkon-qe-qeveria-tendaloje-me-standardet-e-dyfishta

- https://vesnik-ilinden.com/vo-struga-se-odrzha-najmasovnata-litija-za-gurgovden

- $\quad$ https://vlada.mk/uredbi-covid19

- https://www.aleanca.eu/qeveria-te-ndaloje-me-standardet-e-dyfishta

- https://www.almakos.com/kisha-ortodokse-maqedonase-vazhdon

- https://www.fakulteti.mk/news/20032020/shto-tochno-znachi-vonredna-sostojba-objasnuvaprof-oliver-bakreski

- https://www.ohchr.org

- https://www.slobodnaevropa.mk 